\title{
Pemanfaatan Eceng Gondok Menjadi Pupuk Organik Cair Di Desa Batujai Kabupaten Lombok Tengah
}

\author{
Rizal Aidi' ${ }^{1}$ I Gusti Putu Muliarta Aryana*2, I Nyoman Hendri Oka Suardika ${ }^{3}$, \\ Khilda Khairunnisa Fakhruddin ${ }^{4}$ \\ ${ }^{1}$ Prodi Managemen Fakultas Ekonomi, ${ }^{2}$ Prodi Agroekoteknologi Fakultas Pertanian, ${ }^{3}$ Prodi Ilmu \\ Komunikasi, ${ }^{4}$ Prodi Hubungan Internasional \\ Universitas Mataram, Mataram, Indonesia.
}

\section{Article history}

Received: 09-11-2021

Revised: $18-11-2021$

Accepted: 25-11-2021

*Corresponding Author:

I Gusti Putu Muliarta

Aryana

Prodi Agroekoteknologi

Fakultas Pertanian

Universitas Mataram,

Jl. Majapahit No. 62,

Mataram, Lombok-Nusa

Tenggara Barat, Indonesia

Email:

muliarta1@yahoo.co.id

\begin{abstract}
Eceng Gondok in Batujai Dam, West Praya District, Central Lombok Regency is a serious problem for the government because of its rapid growth and can damage air sedimentation. The purpose of this activity is to provide counseling and training on the use of Eceng Gondok to become liquid organic fertilizer for the community in Batujai Village. The counseling and training activities were attended by 19 hamlet heads, community leaders, and village youth. This service activity is carried out in several stages, namely surveys, holding counseling as a form of learning assistance, training, and evaluation. This activity was carried out from April to July 2021. Counseling and training on the manufacture of liquid organic fertilizer with Eceng Gondok as raw material was carried out in the Batujai Village Office Hall. The results showed that the participants felt very helpful with the outreach activities regarding the importance of Eceng Gondok to be used as liquid organic fertilizer. Participants have more insight and skills in the Training of Making Organic Liquid Fertilizer (OLF). The resulting Liquid Organic Fertilizer product is applied to plants with an unquestionable level of testing and a $\mathrm{Ph}$ that is safe for plants. The introduction of this OLF product is a solution for the Batujai Village community to participate in the use of water hyacinth which is a weed as a government participation program in the form of Zero Waste.
\end{abstract}

Keywords: eceng gondok; fermentation; liquid organic fertilizer

Abtrak: Eceng gondok di Bendungan Batujai, Kecamatan Praya Barat, Kabupaten Lombok Tengah merupakan masalah serius bagi pemerintah karena pertumbuhannya yang cepat dan dapat merusak sedimentasi air. Tujuan dari kegiatan ini adalah melakukan penyuluhan dan pelatihan pemanfaatan eceng gondok untuk menjadi pupuk organik cair pada masyarakat di Desa Batujai. Kegiatan penyuluhan dan pelatihan dihadiri oleh 19 kepala dusun, tokoh masyarakat, dan pemuda desa. Kegiatan ini dilaksanakan dalam beberapa tahap, yaitu survay, mengadakan penyuluhan sebagai bentuk pendampingan pembelajaran, pelatihan, dan evaluasi. Kegiatan ini dilakukan mulai bulan AprilJuli 2021. Penyuluhan serta pelatihan pembuatan pupuk organik cair dengan bahan baku eceng gondok dilaksanakan di Aula Kantor Desa Batujai. Hasil kegiatan menunjukan bahwa peserta merasa sangat terbantu dengan telah dilakukannya kegiatan penyuluhan mengenai pentingnya pengolahan eceng gondok untuk dijadikan pupuk organik cair. Peserta pelatihan memiliki wawasan yang lebih dan terampil dalam Pembuatan Pupuk Cair Organik (POC). Produk Pupuk Organik Cair yang dihasilkan sudah diterapkan pada tumbuhan dengan tingkat pengujian unsur hara dan $\mathrm{PH}$ yang aman bagi tanaman. Pengenalan produk POC ini menjadi solusi masyarakat Desa Batujai untuk ikut serta dalam pemanfaatan eceng gondok yang merupakan gulma sebagai bentuk partisipasi 
program pemerintah berupa Zero Waste.

Kata Kunci: : Eceng Gondok; Fermentasi; Pupuk Organik Cair

\section{PENDAHULUAN}

Permasalahan eceng gondok sebagai limbah di Bendungan Batujai merupakan masalah serius bagi pemerintah pusat karena pertumbuhannya yang begitu cepat dan tidak terkendali. Hal ini menyebabkan negara harus mengeluarkan dana sebesar 50 milliar untuk mengangkat eceng gondok dan mengeruk permukaan bendungan yang dangkal akibat sedimentasi oleh tumbuhan liar tersebut (Euthalia, 2007). Selain itu, pemerintah juga berupaya untuk bagaimana limbah eceng gondok ini dapat di manfaatkan secara baik dan benar.

Eceng gondok merupakan tumbuhan air yang banyak terdapat di perairan tawar seperti sungai, kolam dan bendungan. Eceng gondok memiliki kecepatan pertumbuhan yang pesat sehingga tumbuhan ini dianggap sebagai gulma yang dapat merusak lingkungan perairan. Pertumbuhan eceng gondok dapat semakin baik bila air yang menjadi media tumbuhnya tercemar oleh limbah pertanian ataupun limbah pabrik. Bendungan Batujai ialah salah satu bendungan di Lombok, Nusa Tenggara Barat yang kini memiliki permasalahan terkait eceng gondoknya (Sirojul, 2003).

Masalah ini sudah menjadi persoalan besar bagi pemerintah daerah dan pusat dengan anggaran yang cukup besar untuk menanganinya. Faktor pertumbuhan yang optimum bagi eceng gondok adalah air yang dangkal, ruang tumbuh yang luas, air yang tenang, sinar matahari yang cukup, unsur hara yang cukup, dan tingkat keasaman air atau $\mathrm{Ph}$ antara 7 sampai 7,5. Ketenangan air merupakan faktor yang sangat penting bagi pertumbuhan eceng gondok. Keadaan air yang bergerak karena mengalir atau bergelombang merupakan faktor penghambat perkembangbiakannya. (Euthalia,2007). Hal ini yang mengakibatkan pertumbuhan massal enceng gondok terjadi di Bendungan Batujai, karena air yang berada di bendungana tersebut tenang dan tidak bergelombang.

Permasalahan eceng gondok di Bendungan Batujai menjadi tugas bersama untuk menanganinya. Berdasarkan beberapa artikel, eceng gondok dapat di manfaatkan menjadi produk yang dapat digunakan, salah satunya pupuk organic cair. Pemanfaatan ini merupakan langkah kecil untuk mengajak masyarakat agar ikut berpartisipasi dalam program pemerintah NTB berupa Zero Waste. Masyarakat dapat merubah mindset tentang eceng gondok sebagai limbah yang sebelumnya menjadi masalah, kini berubah sebagai produk berguna. Sebab eceng gondok sendiri memiliki banyak manfaat bagi kesuburan tanah dan pertumbuhan tanaman dengan POC tersebut. Melalui kegiatan ini, dapat memberikan perspektif baru kepada masyarakat khususnya Desa Batujai untuk memanfaatkan tumbuhan eceng gondok terutama pada sektor pertanian.

\section{METODE}

Program pengabdian ini dilaksanakan di Aula Kantor Desa Batujai, Kecamatan Praya Barat, Kabupaten Lombok Tengah, bersama 19 kepala dusun, tokoh masyarakat dan pemuda desa setempat. Kegiatan pengabdian kepada masyarakat dilakukan oleh tim mahasiswa KKN yang bekerja sama dengan BPTP NTB sebagai tim penyuluh, pendampingan edukasi serta pelatihan pembuatan Pupuk Organik Cair (POC). Kegiatan ini dilakukan mulai April - Juli 2021 yang meliputi survai, penyuluhan, pendampingan pelatihan, dan evaluasi.

Alat yang digunakan dalam kegiatan ini adalah blender, ember, pisau, gelas ukur dan pengaduk. Bahan yang digunakan adalah eceng gondok, toge, molase, EM4, air, plastik dan tali rapia. Pelaksanaan kegiatan pengabdian masyarakat ini dilaksanakan dalam beberapa tahapan yaitu : 


\section{Melakukan Survay}

Kegiatan survai dilakukan untuk mengetahui potensi eceng gondok yang dapat dimanfaatkan sebagai pupuk organik cair.

\section{Penyuluhan}

Kegiatan penyuluhan dilakukan dengan tujuan memberikan edukasi kepada masyarakat betapa pentingnya pemanfaatan eceng gondok sebagai gulma dan limbah perairan, serta memberikan teori tentang pembuatan pupuk organic cair dengan eceng gondok sebagai salah satu bahan utamanya. Penyuluhan dilaksanakan di aula kantor desa Batujai dengan menghadirkan seluruh kepala dusun,tokoh masyarakat serta pemuda desa.

\section{Pendampingan Pelatihan}

Pendampingan pelatihan merupakan bentuk kegiatan praktek dari teori yang telah diberikan sebelumnya. Pelaksaan ini dilakukan oleh tim mahasiswa bekerja sama dengan BPTP NTB sebagai tim penyuluh. Kegiatan pelatihan pembuatan pupuk organik cair ini terdiri atas beberapa tahap:

Tahap pengambilan eceng gondok, pemilihan eceng gondok yang masih segar yang berada di air untuk mendapatkan kualitas yang baik.

Tahap pemotongan, proses pengirisan batang eceng gondok menjadi bagian kecil agar mudah diolah.Tahap pengolahan, eceng gondok yang sudah di potong kecil kemudian dimasukkan kedalam blender berisi air, selanjutnya disaring untuk mengambil airnya.

\section{Evaluasi}

Evaluasi kegiatan dilakukan setelah kegiatan penyuluhan dan pelatihan, evaluasi meliputi evaluasi tingkat partisipasi peserta, evaluasi terhadap kualitas produk POC yang dihasilkan.

\section{HASIL DAN PEMBAHASAN}

Sebelum melakukan kegiatan pelatihan, mahasiswa melakukan persiapan terlebih dahulu agar kegiatan berjalan sesuai dengan yang diharapkan. Persiapan diawali dengan survay lokasi untuk keberadaan eceng gondok di bendungan Batujai. Kemudian dilanjutkan dengan menyepakati jadwal dan lokasi diadakannya penyuluhan dan pelatihan. Persiapan selanjutnya yaitu dengan menyiapkan materi dan juga menyiapkan alat dan bahan yang digunakan

Pada minggu kedua pengabdian dilakukan kegiatan penyuluhan di Aula Kantor Desa yang diawali dengan sambutan oleh sekretaris desa kemudian disusul dengan penyampaian materi penyuluhan oleh mahasiswa KKN. Materi yang disampaikan meliputi pemanfaatan tumbuhan eceng gondok menjadi pupuk organik cair. Pada minggu keempat pelatihan pembuatan pupuk organik cair dilakukan di tempat yang sama. Pelatihan dipandu oleh tim dari BPTP NTB. 

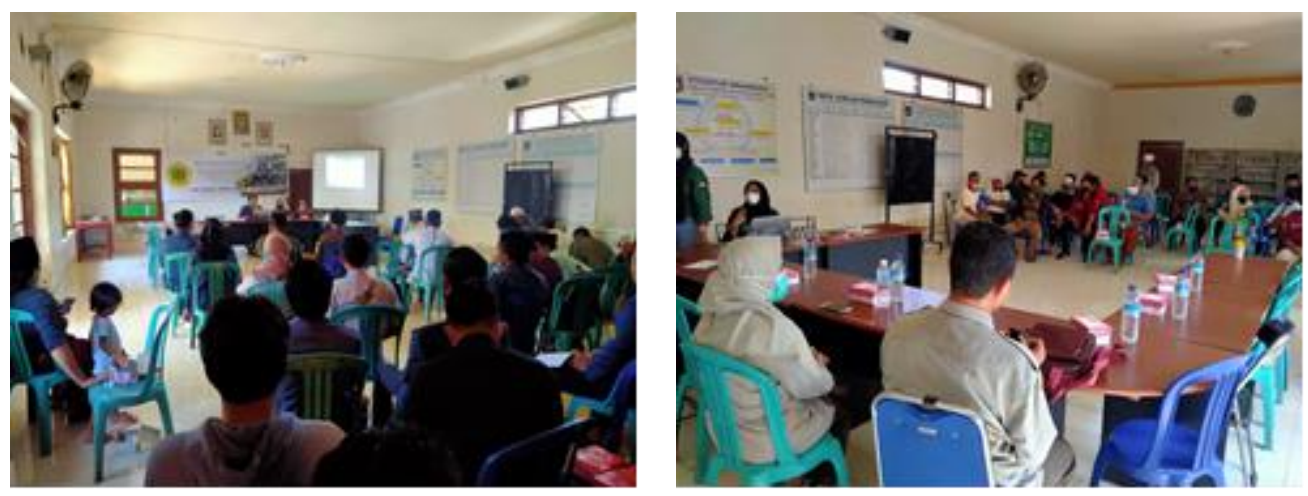

Gambar 1. kegiatan penyuluhan dan pelatihan

Manfaat yang di hasilkan oleh tim pelaksana dari mahasiswa dan tim penyuluh BPTP adalah memberikan edukasi. Masyarakat sadar dan berfikir secara obyektif bahwa eceng gondok yang merupakan limbah yang tidak terkendali dan merusak pemandangan bendungan dapat dimanfaatkan menjadi pupuk organik cair (POC) pada tanaman.

Pupuk Organik Cair dari eceng gondok dinilai lebih efektif untuk tanaman dan menjaga kesuburan tanah. Beberapa keunggulan pupuk organik ini diantaranya, bisa mempertahankan struktur tanah, menyuburkan tanah, mempercepat pertumbuhan tanaman, dan mendorong pertumbuhan akar muda. Pupuk organik cair dari eceng gondok ini memiliki manfaat untuk memacu pertumbuhan tanaman, mampu mendorong dan meningkatkan pembentukan klorofil daun, sehingga meningkatkan kemampuan fotosintesis tanaman. Pupuk organik cair dari eceng gondok ini lebih ramah lingkungan jika dibandingkan dengan pupuk anorganik. Selain itu juga manfaat bagi petani, harga pupuk organik cair Eceng Gondok lebih terjangkau (Taufika,2011; Eko dkk, 2013).

Bahan yang digunakan dalam pembuatan pupuk organik cair adalah eceng condok, bakteri EM4 pertanian, molase (cairan tebu), toge dan air. Alat yang digunakan adalah blender, saringan, ember, pisau, gelas ukur, tali dan plastik (kain penutup). Proses pembuatan pupuk organik cair dari eceng gondok ini adalah pertama, menyiapkan tumbuhan eceng gondok kemudian diiris/dipotong kecil mengunakan pisau, blender tumbuhan eceng gondok yg sudah dipotong kecil tersebut sampai halus. Kemudian tuangkan bakteri EM4 pertanian $100 \mathrm{ml}$ dan molase (cairan tebu) $50 \mathrm{ml}$ ke dalam 5 liter air. Lalu campurkan campuran tersebut dengan tumbuhan eceng gondok yg sudah dihaluskan sebelumnya. Aduk sampai merata dan tutup dengan plastik. Fermentasikan 7-14 hari. Setelah 7-14 hari, saring menggunakan penyaringan dan kemas kedalam botol bekas tertutup. Perbandingan penggunaan Pupuk Organik Cair (POC) yaitu dosis tinggi $1: 10$ air bersih, dosis sedang $1: 20$, dan dosis rendah $1: 30$.
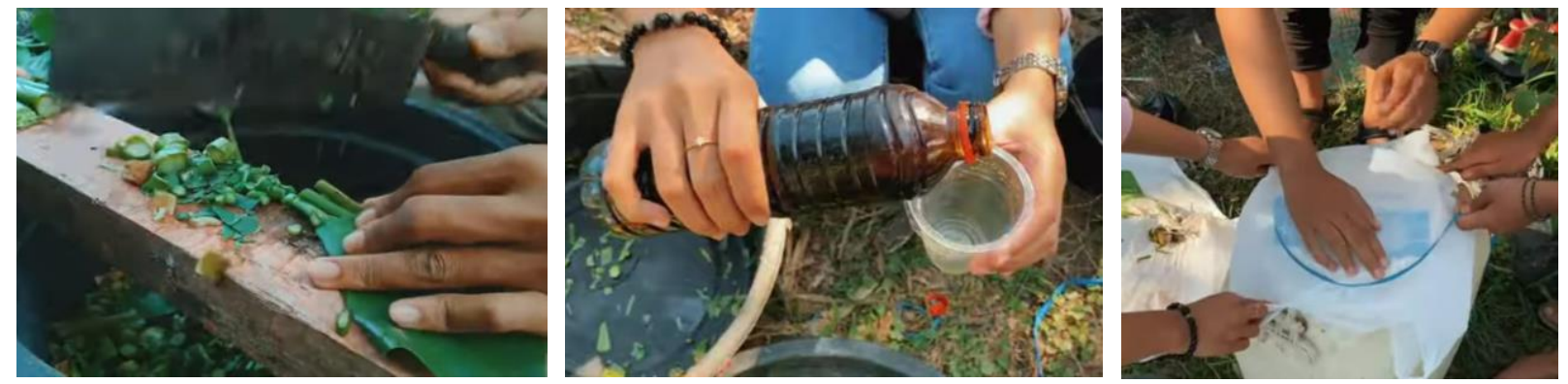

Gambar 2. Proses Pembuatan Pupuk Organik Cair (POC) Eceng Gondok 
Cara pemakaian/mengaplikasikan pupuk organik cair (POC) ada dua cara yaitu sistem pengocoran dan sistem penyemprotan. Sistem pengocoran untuk media tanam dengan menggunakan sistem pot/polybag dalam prosesi fase vegetatif/pertumbuhan, satu tanaman diberikan $250 \mathrm{ml}$ larutan setiap satu tanaman. Sedangkan untuk tanaman dalam prosesi fase generatif/pembuahan diberikan 400 $\mathrm{ml}$ larutan setiap satu tanaman. Pada sistem penyemprotan dilakukan dengan cara disemprotkan mulai dari daun hingga ke bagian batang tanaman, tujuannya adalah untuk menjaga ketahanan tanaman dari serangan hama (Ratnani dkk, 2011). Hasil penelitian Anastatia dkk (2015) pada tanaman sawi menunjukan dengan pemberian pupuk PO eceng gondok $40 \%$ (40 ml pupuk dan $60 \mathrm{ml}$ air) mampu meningkatkan tinggi tanaman, jumlah daun serta berat basah dan kering sawi.

Dari hasil evaluasi menunjukan bahwa peserta penyuluhan dan pelatihan sangat antusias dalam menerima inovasi baru ini, demikian pula selama dilakukan pendampingan Nampak partisipasi kehadiran peserta tinggi. Terhadap hasil POc yang dihasilkan nampaknya perlu dilakukan uji lanjutan terkait dengan kandungan unsur hara yang dikandungnya. Dari hasil uji kelayakan keamanan penggunaan pada tanaman yang dilakukan berkerjasama dengan dinas pertanian kabupaten Lombok Tengah menunjukan ada pada tingkatan layak digunakan. Perlu dilakukanya demplot untuk tanaman pangan pangan maupun hortikultura untuk melihat responnya terhadap pertumbuhan vegetative dan generative sehingga nantinya lebih meyakinkan para pengguna akan manfaat pupuk organic cair eceng gondok. Beberapa orang peserta juga ada berkeinginan untuk memproduksi sendiri pupuk organic cair eceng gondok.

\section{KESIMPULAN DAN SARAN}

Hasil kegiatan menunjukan bahwa peserta merasa sangat terbantu dengan telah dilakukannya kegiatan penyuluhan mengenai pentingnya pengolahan eceng gondok untuk dijadikan pupuk organik cair. Peserta pelatihan memiliki wawasan yang lebih dan terampil dalam Pembuatan Pupuk Cair Organik (POC). Produk Pupuk Organik Cair yang dihasilkan sudah diterapkan pada tumbuhan dengan tingkat pengujian unsur hara dan $\mathrm{Ph}$ yang aman bagi tanaman. Pengenalan produk POC ini menjadi solusi masyarakat Desa Batujai untuk ikut serta dalam pemanfaatan limbah eceng gondok sebagai bentuk partisipasi program pemerintah berupa Zero Waste.

Pupuk Organik air dari eceng gondok yang dihasilkan perlu diuji kandungan unsur hara utama (N, P dan K) kemudian ditidaklanjuti dengan melakukan demplot baik pada tanaman pangan maupun hortikultura. Perlu dilaksankan kegiatan KKN tematik yang berkelanjutan pada desa desa dilingkar bendungan Batujai sehingga masalah eceng gondok yang berada di perairan bendungan dapat teratasi.

\section{Ucapan Terima Kasih}

Ucapan terimakasih kami sampaikan kepada Staf BPTP NTB, Lembaga Penelitian Kepada Masyarakat (LPPM) Unram sehingga kegiatan penyuluhan dan pelatihan ini dapat terlaksana.

\section{DAFTAR PUSTAKA}

Anastasia R. Moi, Dingse Pandiangan, Parluhutan Siahaan, Agustina M Tangapo, 2015. Pengujian pupuk organic cair dari eceng gondok (Eichhornia crassipes) terhadap pertumbuhan tanaman sawi (Brassica juncea). Jurnal MIPA Unsat online 4(1):15-19.

Eko, J; Churun Ain; Prijadi. 2013. Kandungan Nitrat dan Fosfat Air Pada Proses Pembusukan Eceng Gondok. Diponegoro Journal of Maquares, Vol, 2, No. 4

Euthalia, H.S. 2007. Pengolahan Bahan Organik Eceng Gondok Menjadi Media Tumbuh Untuk Mendukung Pertanian Organik. Jakarta: Jurnal Teknologi Lingkungan Vol.8, No.3 
Ratnani; Rita D; Indah Hartati; Laeli Kurniasari. 2011. Pemanfaatan Eceng Gondok Untuk Menurunkan Kandungan COD. Semarang: Jurnal Momentum, Vol.7, No.1

Sirojul, F. 2003. Eceng Gondok Gulma Sahabat Manusia?. Harian Pikiran Rakyat.

Taufika, R. 2011. Pengujian beberapa dosis pupuk organic cair terhadap pertumbuhan dan hasil tanaman wortel (Doucus corota L). Jurnal Tanaman 1(2):1-10

Yonathan, Arnold, Avianda Rusba P, Bambang Pramudono. 2013. Produksi Biogas Dari Eceng

Gondok (eicchornia crassipes): Kajian Konsistensi dan Ph Terhadap Biogas Dihasilkan. Semarang: Jurnal Teknologi Kimia dan Industri, Vol.2, No.3. 